\title{
Kemampuan Mahasiswa Memahami PersamaAn Diferensial Bernauli melalui Model Pembelajaran Game Menempel Nama
}

\section{STUDENTS' ABILITY IN UNDERSTANDING BERNAULI DIFFERENTIAL EQUATIONS WITH AdHere Name Game Teaching Method}

\author{
Dian Mardiani \\ Program Studi Pendidikan Matematika, Institut Pendidikan Indonesia \\ Jl. Pahlawan No. 32 Sukagalih, Garut, Jawa Barat, Indonesia \\ Alfid51@yahoo.com
}

\begin{abstract}
Abstrak
Tujuan dari penelitian ini adalah untuk mendeskripsikan hasil pengamatan penulis tentang bagaimana game menempel nama diterapkan di perkuliahan Persamaan Diferensial pada tema Persamaan Diferensial Bernauli? Ini merupakan penelitian deskriptif. Observasi dilakukan di salah satu kelas mata kuliah Persamaan Diferensial di STKIP Garut. Instrument penelitian yang digunakan berupa lembar observasi untuk mengeksplorasi bagaimana metode game menempel nama digunakan dalam suatu perkuliahan persamaan diferensial. Berdasar hasil observasi diperoleh game ini membuat peserta didik lebih bergairah mendrill kemampuannya dalam menentukan solusi suatu persamaan diferensial Bernauli secara mandiri. Drill berulang untuk mahir menggunakan prosedur tertentu tak terasa membosankan bagi peserta didik, dengan harapan namanya dapat tertempel lebih banyak dari teman lainnya. Dengan game ini, diperoleh produk berupa buku lipat warna warni berisikan soalyang beragam dan penyelesaiannya yang dapat digunakan sebagai bank soal.

Kata Kunci: game, menempel nama, persamaan diferensial Bernauli.
\end{abstract}

\begin{abstract}
The goal of this study is to describe the result of the research by the writer about how adhere name games be applied in teaching and learning Differential Equations with Bernauli Differential Equations theme? This study is descriptive study. An observation was conducted in one of classes with Differential Equations in STKIP Garut. Instrument used in this study was observation sheets to explore how Adhere Name Method used in one of Differential Equations subject. Based on the observation, the game made the students more enjoy in drilling their ability in deciding a solution of Bernauli Differential Equations independently. Continuity drill make skilled in using certain procedure wouldn't bore for students, with hopes their names could adhere more than other friends. With this game, it produced colorful fold book contained variety questions and the answer that can be used as bank questions.

Keyword: Game, Adhere Name Games, Bernauli Differential Equation.
\end{abstract}




\section{Pendahuluan}

Tabel 1.

Pendapat Mahasiswa STKIP Garut Prodi Matematika (Desember 2017) Tentang Belajar Matematika yang Asyik

\begin{tabular}{lc|}
\hline $\begin{array}{c}\text { Belajar matematika } \\
\text { dikatakan asyik jika: }\end{array}$ & Persentase $\%$ \\
\hline Tidak membosankan & $30 \%$ \\
\hline Seru/ menyenangkan & $24 \%$ \\
\hline Tidak tegang ( rileks) & $21 \%$ \\
\hline Mudah dipahami & $19 \%$ \\
\hline Ada permainan & $15 \%$ \\
\hline
\end{tabular}

Peserta didik senantiasa berharap pembelajaran yang diberikan gurunya, tidak membosankan, sehingga mereka enjoy dalam belajar. Hasil survey terhadap mahasiswa program studi matematika STKIP Garut yang dilakukan bulan Desember 2017 baru baru ini, memberikan fakta yang demikian. Sebagai pengajar, sangat perlu berupaya bagaimana membawa mahasiswa sebagai peserta didik, senang dengan proses perkuliahan, sehingga dengan rela mereka belajar untuk meraih hasil belajar setinggitingginya.

Kegiatan belajar mengajar merupakan suatu kondisi yang sengaja diciptakan oleh pendidik dengan peserta didik, dan peserta didik dengan peserta didik lainnya serta memanfaatkan medium secara optimal untuk mencapai tujuan yang telah ditetapkan. (Syaiful dalam Mujahidin: 2017). Kegiatan belajar mengajar mata kuliah Persamaan Diferensial selama ini belum pernah menggunakan variasi metode game. Karakter materi yang dikuliahkan di mata kuliah ini, cukup sulit untuk disisipi metode game. Banyak materi yang mengasah kemampuan prosedural dalam bermatematika, dalam hal ini mencari solusi suatu persamaan diferensial. Dan prosedurnya cukup panjang, perlu ketenangan, ketelitian, pantang menyerah dalam menguasainya. Sementara para mahasiswa sangat berharap perkuliahan jangan terasa monoton.

Melalui penelitian ini, penulis mencoba menggunakan game menempel nama, untuk memberikan sedikit kesan berbeda, ketika mereka malakukan drill berulangulang untuk terampil melakukan prosedur tertentu dalam mencari solusi dari suatu persamaan diferensial. Harapan penulis, game ini dapat memberikan tambahan pengalaman positif dalam bermatematika, juga dapat terwujud karya berupa kumpulan soal jawab, dari tema yang dimainkan di game.

Pertanyaan penelitian yang ingin dibahas di tulisan ini sebagai berikut:

1. Yang bagaimanakah yang dinamai game menempel?

2. Bagaimana hasil dari penerapan game menempel nama pada perkuliahan persamaan diferensial, khususnya pada tema persamaan diferensial bernauli.

Suyadi (2013) memberikan strategi pembelajaran pendidikan karakter yang dapat dipilih guru. Dalam bukunya Suyadi menjelaskan beberapa strategi pembelajaran yang dapat dipilih guru di antaranya: active learning bermuatan karakter, cooperative learning bermuatan karakter, pembelajaran contextual teacing 
and learning (CTL) bermuatan karakter, quantum learning bermuatan karakter, pembelajaran inkuriri bermuatan karakter, problem based learning bermuatan karakter, strategi pembelajaran ekspositori bermuatan karakter, pembelajaran aktif, kreatif, efektif, dan menyenangkan bermuatan karakter, srtrategi pembelajaran inovatif bermuatan karakter, dan strategi pembelajaran aktif bermuatan karakter. Untuk cooperative learning Robert E Slavin (2009) membahas dengan lebih rinci berdasarkan teori, riset dan praktek para ahli. Sangat banyak teori tentang bagaimana seharusnya mengajar matematika yang efektif tapi asyik. Ketika game menempel nama dimainkan prinsip mengajar dengan melatihkan karakterkarakter baik juga diterapkan.

Hamalik (2003) menyatakan bahwa Belajar adalah suatu proses, suatu kegiatan dan bukan suatu hasil dan tujuan. Dipilih game menempel nama di perkuliahan Persamaan Diferensial pada tema Persamaan Diferensial Bernauli, diharapkan membantu proses belajar persamaan diferensial secara keseluruhan.

Mengajar dengan efektif adalah tujuan seharusnya pembelajaran. Disadari atau tidak, kita sebagai guru harus mampu mengelola pembelajaran supaya berkesan asyik supaya kita sebagai pendidik juga anak didik kita merasa enjoy belajar sehingga anak didik kita berhasil menguasai konsep-konsep matematika yang kita ajarkan, bahkan tujuan besarnya mereka mampu belajar sepanjang hayat untuk menguasai matematika lebih dari yang kita ajarkan.

Persamaan diferensial Bernauli adalah persamaan yang memiliki bentuk umum $\frac{d y}{d x}+P(x) \cdot y=y^{n} \cdot Q(x)$. Solusi umum dari persamaan diferensial Bernauli adalah $y^{1-n}=$ $e^{(n-1) \int P(x) d x}\left[\int e^{(1-n) P(x) d x} \cdot Q(x) d x+\right.$ C]

Selain dengan rumus di atas, solusi umumnya dapat dicari dengan menggunakan rumus Lagrange-Bernauli: $y^{1-n}=\frac{1-n}{S(x)}\left[\int S(x) \cdot Q(x) d x+C\right]$ dengan $S(x)=e^{(1-n) \int P(x) d x}$. Untuk $\mathrm{n}=0$, kita boleh menggunakan rumus Lagrange Bernauli, dapat pula mengubah terlebih dahulu persamaan diferensial Bernauli menjadi persamaan diferensial linear tingkat 1 berderajat 1 sehingga mencari solusinya dapat menggunakan rumus $y=$ $e^{-\int P(x) d x}\left[\int Q(x) \cdot e^{\int P(x) d x} d x+C\right]$.

Melihat rumusnya saja perlu mental kuat agar mahasiswa mau tidak sekedar mengetahui, namun mampu memahami dan menggunakan rumus-rumus tersebut. Menguasai suatu prosedur, menerapkan suatu rumus, perlu upaya berulang-ulang dengan penuh kesungguhan. Biasanya metode perkuliahan dipilih tanpa melibatkan game.

Penting bagi kita selaku pengajar matematika berusaha agar siswa kita memiliki kemandirian dalam belajar matematika karena berdasar hasil penelitian (Dian: 2001) menunjukkan bahwa siswa berprestasi memiliki kemandirian dalam belajar matematika 
terutama dalam berlatih soal-soal matematika. Game menempel nama dipilih agar mahasiswa bisa berhasil terampil menentukan solusi umum persamaan diferensial Bernauli, dengan cara mendapat kesempatan secara mandiri melatih menggunakan rumus yang ingin mereka latih, dalam suasana game yang membawa relax, terpacu mendapat hadiah namun kondusif, tidak ada hingar bingar sorak soray kemenangan. Hadiah game ini adalah suatu pengakuan akan usaha mereka berlatih, berupa karya mereka dengan nama mereka tertempel di buku lipat. Bagaimana game ini secara detailnya akan di bahas di bab pembahasan.

Game yang dipilih sebaiknya yang memberikan kesempatan mahasiswa melakukan usaha secara mandiri, sehingga sesuai dengan pernyataan Sigit Wahyudi (1995:77) berdasar hasil penelitiannya bahwa ada korelasi positif yang signifikan antara kemandirian dalam belajar dengan prestasi belajar. Hal ini merupakan bukti bahwa kemandirian belajar matematika berperan penting dalam kesuksesan siswa bermatematika. Untuk memperoleh hasil belajar yang sesuai harapan, peneliti memilih metode game "menempel nama" untuk membelajarkan mahasiswa dalam mata kuliah Persamaan Diferensial. Tujuannya agar mahasiswa merasa asyik berlatih prosedur mencari solusi dari persamaan diferensial Bernauli, salah satu tema yang dikaji di mata kuliah ini.

Burton mengusulkan dalam (Tim MKPBM Jurusan Pendidikan Matematika:
2001) bahwa tanggung jawab guru dalam proses belajar adalah untuk menstimulasi dan memotivasi siswa, menyediakan pengalaman untuk menumbuhkan pemahaman, mendiagnosa dan mengatasi kesulitan siswa, dan mengevaluasi. Banyak metode pembelajaran matematika yang dapat dipilih untuk memenuhi tanggung jawab itu, di antaranya: metode ceramah, metode ekspositori, metode drill, metode demonstrasi, metode tanya jawab, metode penemuan, metode inkuiri, metode permainan dan metode pemberian tugas (Tim MKPBM Jurusan Pendidikan Matematika: 2001). Kita mencoba metode game menempel nama tidak bertentangan dengan Tim MKPMB, bahkan kita memiliki peluang untuk membangkitkan rasa senang, motivasi belajar mahasiswa dengan pilihan ini. Menurut Daryanto dalam (Ari: 2016) pendidik berkewajiban membangkitkan motivasi siswa sehingga ia mau melakukan belajar.

Permainan matematika diharapkan dapat menjadi kegiatan menggembirakan yang dapat menunjang tercapainya tujuan intruksional matematika dalam aspek kognitif, afektif, dan psikomotor sehingga dapat meningkatkan motivasi belajar, keterampilan pemahaman konsep, dan pemantapannya. Pada penelitian terdahulu, untuk perkuliahan Matematika Diskrit dengan tema sejarah dan teori graf dipilih game "tantangan berhadiah point". Yang hasilnya baik dari segi mendapat respon positif anak didik. Game menempel nama memiliki tantangan lebih, berupa 
tujuan game ke efektif atau tidaknya suatu perkuliahan. Melalui game menempel nama mahasiswa dilatih pula kemampuan komunikasi matematika tertulisnya. Kemampuan ini penting untuk dilatihkan. Hulukati dalam (Asep Saepuloh, 2013) menyatakan bahwa kemampuan komunikasi matematis siswa sangat penting dikembangkan pada proses pembelajaran karena kemampuan ini merupakan syarat untuk memecahkan masalah.

\section{Metode}

Penelitian ini merupakan suatu penelitian deskriptif. Subjek penelitian dari penelitian ini adalah suatu kelas di Prodi Pendidikan Matematika pada mata kuliah Persamaan Diferensial, dengan tema Persamaan Diferensial Bernauli. Instrumen penelitian ini berupa lembar pengamatan, angket dan tes. Lembar pengamatan bertujuan untuk menuliskan hasil pengamatan terhadap mahasiswa selama proses belajar berlangsung. Angket untuk mengetahui pendapat mahasiswa tentang game ini. Sedangkan tes diberikan untuk mengetahui efektif tidaknya game menempel nama ini.

\section{Hasil dan Pembahasan}

\section{A. Game Menempel Nama (GMN)}

Game ini digunakan untuk membelajarkan prosedur matematika. Yang cocok untuk menggunakan game ini kemungkinan misalnya melatih peserta didik menggunakan rumus tertentu. Rumus yang dilatihkan dapat yang cukup sulit untuk dicongak. Materi yang dibelajarkan dapat yang karakternya cukup sulit dipahami dengan didemonstrasikan saja, dan perlu latihan berulang-ulang untuk memahami materi tersebut.

Game ini, biayanya murah. Pengajar cukup menyiapkan beberapa helai karton, kertas warna, gunting dan lem. Pembelajaran berlangsung dalam 2 tahap.

Tahap pertama, pengajar memberikan informasi tentang materi berupa prosedur matematika yang ingin dibelajarkan. Kemudian pengajar memberikan contoh jika diperlukan.

Dalam penelitian ini, prosedur yang dibelajarkan adalah rumus mencari solusi umum dari persamaan diferensial Bernauli dengan $n=0$. Ada dua cara dan mahasiswa ditantang untuk melatih kedua cara tersebut. Cara pertama mahasiswa mengubah persamaan diferensial bernauli menjadi persamaan diferensial linear lalu menyelesaikannya atau mencari solusi umumnya. Cara kedua, mahasiswa langsung menggunakan rumus LagrangeBernauli.

Tahap kedua, mahasiswa secara mandiri melakukan drill berulang-ulang sesuai kemampuannya untuk memahami dan terampil menggunakan kedua prosedur tersebut. Soal yang dipecahkan, mereka boleh ambil dari buku sumber, atau mengarang soal sendiri, lalu dijawab sendiri. Dalam tahap ini mahasiswa boleh konsultasi, diskusi, dengan teman dan juga dengan pengajar. Ketika soal dan jawaban mereka berhasil benar, mereka berhak menuliskan soal dan jawabannya pada 
kertas warna, yang boleh mereka gunting bentuknya seperti apa yang mereka mau dengan menggunakan gunting. Dan hadiahnya, nama mereka bisa diukir dikertas tersebut, lalu ditempel di karton yang dijadikan buku lipat, nantinya. Mahasiswa dan dosen bekerja sama agar mereka berhasil memahami dan mampu menggunakan prosedur yang diajarkan. Rasa senang mahasiswa ketika nama mereka tertempel di buku lipat lebih dari satu kali. Ada juga yang terlihat sangat puas dengan mendekor kertas warnanya sehingga tampak indah ketika ditempel di buku lipat. Perkuliahan berakhir ketika waktu perkuliahan habis.

Bagi yang merasa belum puas karena belum bisa menempel namanya lebih dari satu kali, mereka diperkenankan melatih sendiri di rumah di buku mandiri, dengan hadiah satu soal dilatih, imbalannya satu point. Jika mereka gagal memahami materi yang dibelajarkan, tidak ada hukuman, melainkan mereka diberi waktu konsultasi di luar jam perkuliahan.

\section{B. Hasil Pengamatan Menggunakan Game Menempel Nama pada Pembelajaran Persamaan Diferensial Bernauli}

Berdasar hasil pengamatan ketika berlangsungnya perkuliahan, penggunaan game ini tidak menimbulkan kegaduhan yang mengakibatkan terganggunya kelas lain yang sedang belajar. Suasana hati mahasiswa rileks, mereka serius berlatih, dan tidak sungkan bertanya ke meja dosen memperlihatkan hasil mereka, mengkonsultasikan kesulitan yang dihadapi. Mereka tidak terburu-buru dalam mengerjakan, mengingat perlunya konsentrasi dan ketelitian. Teriakan yes sesekali terdengar dari yang baru berhasil memecahakan satu soal.

Penggunaan game menempel nama, walau dipandang mahasiswa biasa saja dari segi inovatifnya, namun mampu menjembatani hubungan social yang lebih baik antara dosen dengan mahasiswa. Di game ini, mahasiswa merasakan bahwa dosen mereka serius ingin membantu mereka supaya paham. Tugas mengerjakan soal, berlatih secara mandiri di rumah, mereka kerjakan dengan senang, tidak merasa terbebani. Dan dari hasil tes, semuanya berhasil menyelesaikan soal mencari solusi umum dari persamaan diferensial bernauli, bahkan mereka berhasil di materi-materi lainya di perkuliahan ini, sehingga hasil ujian mereka $100 \%$ lulus di atas nilai C.

Mengapa fenomena ini bisa terjadi? Mungkin karena mereka berhasil mengembangkan dirinya, belajar secara mandiri. Penelitian kali ini lagi-lagi memberikan fakta bahwa kemandirian dalam belajar sangat penting bagi keberhasilan. Efektif tidaknya pembelajaran, dipengaruhi kuat oleh mau tidaknya peserta didik belajar secara mandiri. Game hanya alat untuk memaksa secara halus dan menyenangkan, tanpa tekanan, agar mahasiswa mau belajar secara mandiri sampai berhasil. Hal lainnya yang penting adalah totalitas pengajar 
dalam memberikan pelayanan. Tidak terbatas di ruang kelas.

Penggunaan game menempel nama berdasar observasi mampu memberikan suatu pembelajaran yang maknanya sesuai dengan yang dituliskan Sundayana (2013) yaitu sebagai proses komunikasi antara pembelajar, pengajar dan bahan ajar. Perkuliahan kental dengan komunikasi antara ketiga unsur tersebut. Sadiman (1993) menyatakan secara umum tentang fungsi media. Dan game ini, terlihat efektif dalam beberapa fungsi yang dipaparkan Sadiman. Game ini fungsinya menimbulkan gairah belajar, interaksi langsung antara siswa dengan sumber belajar, memungkinkan anak belajar mandiri sesuai kemampuannya, memberikan pembelajaran yang lebih menarik.

\section{Penutup}

Berdasar hasil observasi diperoleh game ini membuat peserta didik lebih bergairah mendrill kemampuannya dalam menentukan solusi suatu Persamaan Diferensial Bernauli secara mandiri. Drill berulang untuk mahir menggunakan prosedur tertentu tak terasa membosankan bagi peserta didik, dengan harapan namanya dapat tertempel lebih banyak dari teman lainnya. Dengan game ini, diperoleh produk berupa buku lipat warna warni berisikan soal yang beragam dan penyelesaiannya yang dapat digunakan sebagai bank soal.
Game ini dapat diujicobakan efektifitasnya kepada siswa di sekolah dengan tema yang relevan.

\section{DAFTAR PUstaka}

Hamalik, O. (2003). Kurikulum dan Pembelajaran. Jakarta: PT Bumi Aksara.

Mardiani, Dian. (2001). Karakteristik Gaya Belajar Matematika Siswa Berprestasi pada Sekolah Menengah Umum di Kec. Depok Kab. Sleman DIY Tahun Ajaran 2000/2001. Skripsi. Universitas Negeri Yogyakarta.

Mujahidin, Firdos. (2017). Strategi Mengelola Pembelajaran Bermutu. Bandung: PT Remaja Rosdakarya.

Riswanto, Ari. (2016) "Pengaruh model pembelajaran kooperatif tipe team assisted individualization terhadap motivasi belajar mahasiswa". Mosharafa, volume 5, nomor 3, September.

Sadiman, Arief SA dkk. (1993). Media Pendidikan Pengertian, Pengembangan dan Pemanfaatannya. Jakarta: PT Raja Grafindo Persada.

Saepuloh, R, A. (2013). Penerapan pembelajaran sinektik untuk meningkatkan kemampuan representasi dan komunikasi matematis siswa SMP. UPI. Tersedia http://repository.upi.edu/517/4/T MTK 1102555 CHAPTER 1. pdf[online, diakses tgl 17 November 2016]. 
Sundayana, Rostina. (2013). Media

Pembelajaran Matematika. Bandung:

Alfabeta.

Suyadi. (2013). Strategi Pembelajaran

Pendidikan Karakter. Bandung: PT

Remaja Rosdakarya.

$\begin{array}{crr}\text { Tim MKPBM Jurusan } & \text { Pendidikan } \\ \text { Matematika. } & \text { (2001). } & \text { Strategi } \\ \text { Pembelajaran } & & \text { Matematika }\end{array}$

Kontenporer. Bandung: UPI.

Wahyudi, Sigit. (1995). Peranan Tutorial

dan Kemandirian dalam Belajar

terhadap Prestasi Belajar Mata Kuliah

IImu Alamiah Dasar Mahasiswa

Terbuka di Unit Program Belajar Jarak

Jauh Yogyakarta. Skripsi. IKIP

Yogyakarta.

\section{Riwayat Hidup Penulis}

Dian Mardiani, M. PMat.

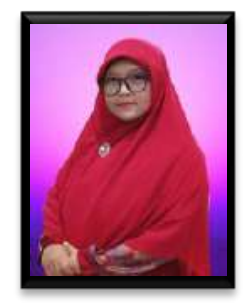

Lahir di Garut, 30 Oktober 1978. Staf pengajar di Institut Pendidikan Indonesia, Garut. Studi S1 Bidang Pendidikan Matematika UNY, Yogyakarta, lulus tahun 2002; S2 Bidang Pengajaran Matematika ITB, Bandung,

lulus tahun 2011. 